\title{
T cells are functionally not impaired in AML: increased PD-1 expression is only seen at time of relapse and correlates with a shift towards the memory $\mathrm{T}$ cell compartment
}

\author{
Frauke M. Schnorfeil ${ }^{1,2+}$, Felix S. Lichtenegger ${ }^{1,2,3^{*}+}$ (D) Katharina Emmerig ${ }^{1,2}$, Miriam Schlueter ${ }^{1,2}$, Julia S. Neitz ${ }^{1,2}$,
} Rika Draenert ${ }^{4}$, Wolfgang Hiddemann ${ }^{1,5}$ and Marion Subklewe ${ }^{1,2}$

\begin{abstract}
Background: T cell function is crucial for the success of several novel immunotherapeutic strategies for the treatment of acute myeloid leukemia (AML). However, changes in phenotype and function of T cells have been described in various hematologic malignancies, mimicking T cell exhaustion known from chronic viral infections. Detailed knowledge about phenotype and function of T cells in AML patients at different stages of the disease is indispensable for optimal development and application of immunotherapeutic strategies for this disease.

Methods: We used flow cytometry-based assays to characterize T cell phenotype and function in peripheral blood and bone marrow of AML patients at diagnosis, at relapse after intensive chemotherapy, and at relapse after allogeneic stem cell transplantation (SCT). Surface expression of CD244, PD-1, CD160, and TIM-3 was determined, and proliferation and production of IFN- $y$, TNF-a, and IL-2 were measured.

Results: We detected similar expression of inhibitory molecules on T cells from patients at diagnosis and from age-matched healthy controls. At relapse after SCT, however, PD-1 expression was significantly increased compared to diagnosis, both on $\mathrm{CD}^{+}$and $\mathrm{CD} 8^{+} \mathrm{T}$ cells. This pattern was not associated with age and cytomegalovirus (CMV) status but with a shift towards effector memory cells in relapsed AML patients. Proliferation and cytokine production assays did not reveal functional defects in T cells of AML patients, neither at diagnosis nor at relapse.
\end{abstract}

Conclusion: We thus conclude that T cell exhaustion does not play a major role in AML. Immunotherapeutic strategies targeting autologous T cells thus have particularly good prospects in the setting of AML.

Keywords: Acute myeloid leukemia (AML), T cell exhaustion, PD-1, Immune checkpoint molecules, Cancer immunotherapy

\section{Background}

Novel immunotherapeutic strategies are increasingly evolving for the treatment of acute myeloid leukemia (AML) $[1,2]$. Many of these strategies inherently rely on the efficiency and functionality of autologous $\mathrm{T}$ cells; a detailed understanding of $\mathrm{T}$ cell function at

\footnotetext{
* Correspondence: felix.lichtenegger@med.uni-muenchen.de

${ }^{\dagger}$ Equal contributors

${ }^{1}$ Department of Internal Medicine III, Klinikum der Universität München, Munich, Germany

${ }^{2}$ Clinical Cooperation Group Immunotherapy, Helmholtz Institute Munich, Munich, Germany

Full list of author information is available at the end of the article
}

different phases of the disease, e.g., at diagnosis and at relapse, is therefore of highest importance for their optimal application. These treatment options include multispecific antibody constructs such as CD33/CD3-bispecific $\mathrm{T}$ cell engaging (BiTE) antibodies [3-5] or other bispecific antibodies [6] that bring the $\mathrm{CD}^{+} \mathrm{T}$ cells in close contact with leukemic cells. Chimeric antigen receptors (CARs) or transgenic $\mathrm{T}$ cell receptors are introduced into patients' $\mathrm{T}$ cells $[7,8]$. And finally, immune checkpoint inhibitors such as PD-1/PD-L1-blocking antibodies 
unleash spontaneously pre-existing tumor- or leukemiaspecific T cells [9-11].

However, different degrees of $\mathrm{T}$ cell dysfunctionality have been described in various hematologic malignancies, including adult $\mathrm{T}$ cell leukemia/lymphoma $[12,13]$, chronic myeloid leukemia [14, 15], and chronic lymphoid leukemia (CLL) [16-18]. These observations have recently been put into the context of $\mathrm{T}$ cell exhaustion, a state of $\mathrm{T}$ cell dysfunction that is defined by increased expression of several inhibitory receptors (CD244, PD-1, CD160, TIM-3, LAG-3) in combination with poor effector function (hypoproliferation, diminished cytokine production, impaired cytotoxicity) and finally apoptosis [19]. It was first described for antigenspecific $\mathrm{T}$ cells in chronic viral infection in mice [20-22] but has since been demonstrated in several human chronic infections, among others in patients with human immunodeficiency virus (HIV) [23-25]. Most of the data has been gathered on $\mathrm{CD}^{+} \mathrm{T}$ cells, but loss of effector function has also been described in virusspecific CD $4^{+} \mathrm{T}$ cells $[26,27]$.

CD244, PD-1, CD160, and TIM-3 are expressed on $\mathrm{T}$ cells and interact with their ligands on antigenpresenting cells upon TCR ligation, resulting in modulation of the $\mathrm{T}$ cell response. CD244, also known as $2 \mathrm{~B} 4$, is a dual-function receptor that mediates activating or inhibitory signals depending on its expression level, extent of ligation, and relative amounts of certain adaptor molecules [28]. PD-1 limits $\mathrm{T}$ cell responses in infection [29] and autoimmunity [30]. Tumors can exploit this axis to escape the immune system by constitutive or inducible expression of PD-1 ligand [31]. CD160 coinhibits $\mathrm{CD} 4^{+} \mathrm{T}$ cells upon ligand binding [32], and when coexpressed with PD-1, it also inhibits $\mathrm{CD} 8^{+} \mathrm{T}$ cells [33]. TIM-3 inhibits Th1 T cells by binding to galectin-9 [34] and has been shown to promote $\mathrm{T}$ cell exhaustion during chronic viral infection [35] and in cancer [36, 37].

So far, data on $\mathrm{T}$ cell function or potential $\mathrm{T}$ cell exhaustion in AML is mainly based on the analysis of murine models. In a syngeneic AML model, it was reported that coexpression of PD-1 and TIM-3 defined a subset of $\mathrm{CD}^{+} \mathrm{T}$ cells deficient in cytokine production. During AML progression, the number of these cells increased [38].

In our study, we set out to analyze the phenotype (with a particular focus on the inhibitory molecules CD244, PD-1, CD160, and TIM-3) and function (proliferation, cytokine production) of peripheral blood $(\mathrm{PB})$ and bone marrow (BM) T cells in AML patients at different stages of the disease (diagnosis, relapse after intensive chemotherapy, relapse after allogeneic stem cell transplantation (allo$\mathrm{SCT})$ ) in comparison to healthy controls (HC) and untreated HIV-infected patients.

\section{Results}

Increased levels of CD244, PD-1, CD160, and TIM-3 were expressed on peripheral blood $\mathrm{CD}^{+}$and $\mathrm{CD}^{+} \mathrm{T}$ cells of untreated HIV patients compared to healthy controls CD244, PD-1, CD160, and TIM-3 are the most prominent inhibitory molecules upregulated in the context of $\mathrm{T}$ cell exhaustion. As a positive control, we analyzed $10 \mathrm{HIV}$ patients before the start of highly active antiretroviral therapy (HAART) in comparison to 30 HC. In order to prevent an age bias, samples were categorized according to age ( $\leq 40$ vs. $>40$ years $)$ within both groups (Fig. 1).

$\mathrm{CD}^{+} \mathrm{T}$ cells of younger ( $\leq 40$ years) HIV patients showed a strong increase in expression levels compared to the respective $\mathrm{HC}$ for CD244 (median of 78.2 vs. $34.8 ; n=4$ and $n=15 ; p=0.0005$; Fig. $1 \mathrm{a}$ ), PD-1 (median of 39.9 vs. $18.5 ; n=4$ and $n=15 ; p=0.0005$; Fig. 1b), and CD160 (median of 42.0 vs. $17.8 ; n=4$ and $n=15 ; p=0.0005$; Fig. 1c). For TIM-3, there was only a non-significant trend towards higher expression (median of 8.6 vs. $0.7 ; n=2$ and $n=6 ; p=0.07$; Fig. $1 \mathrm{~d}$ ). In the older age group ( $>40$ years), differences to $\mathrm{HC}$ were less pronounced and not statistically significant, but expression was still higher in the HIV patients for each molecule: CD244 (median of 65.9 vs. $60.9 ; n=6$ and $n=15 ; p=0.52$; Fig. 1a), PD-1 (median of 26.7 vs. $14.8 ; n=6$ and $n=15 ; p=0.16$; Fig. $1 \mathrm{~b}$ ), CD160 (median of 35.0 vs. 25.7; $n=6$ and $n=15 ; p=0.13$; Fig. 1c), and TIM-3 (median of 1.7 vs. $0.9 ; n=4$ and $n=15 ; p=0.53$, Fig. 1d).

The expression of the inhibitory molecules on $\mathrm{CD}_{4}^{+}$ cells was generally lower and more evenly distributed between both groups. An increased expression was found for PD-1 in HIV patients compared to $\mathrm{HC}$, both in the younger (median of 24.4 vs. $13.0 ; n=4$ and $n=15$; $p=0.004$; Fig. 1f) and in the older cohort (median of 25.2 vs. $10.7 ; n=6$ and $n=15 ; p=0.04$; Fig. 1f). No relevant differences between both groups were found for CD244 (Fig. 1e), CD160 (Fig. 1g), and TIM-3 (Fig. 1h).

\section{Similar levels of CD244, PD-1, CD160, and TIM-3 were expressed on peripheral blood $\mathrm{CD}^{+}$and $\mathrm{CD}^{+} \mathrm{T}$ cells of AML patients at diagnosis compared to healthy controls} In order to evaluate the T cell status of AML patients, we started by immunophenotyping $\mathrm{PB} \mathrm{CD}^{+} \mathrm{T}$ cells from 23 AML patients at diagnosis (AML_diag) in comparison to the $30 \mathrm{HC}$ and $10 \mathrm{HIV}$ patients mentioned above. Again, samples were categorized according to age ( $\leq 40$ vs. $>40$ years) within each group (Fig. 1 ).

In contrast to HIV samples, no relevant increase in inhibitory molecule expression level on $\mathrm{CD}^{+} \mathrm{T}$ cells was found for the AML_diag samples compared to $\mathrm{HC}$, neither for the younger cohort (CD244 median of 43.8; PD-1 median of 15.6; CD160 median of 13.5; 


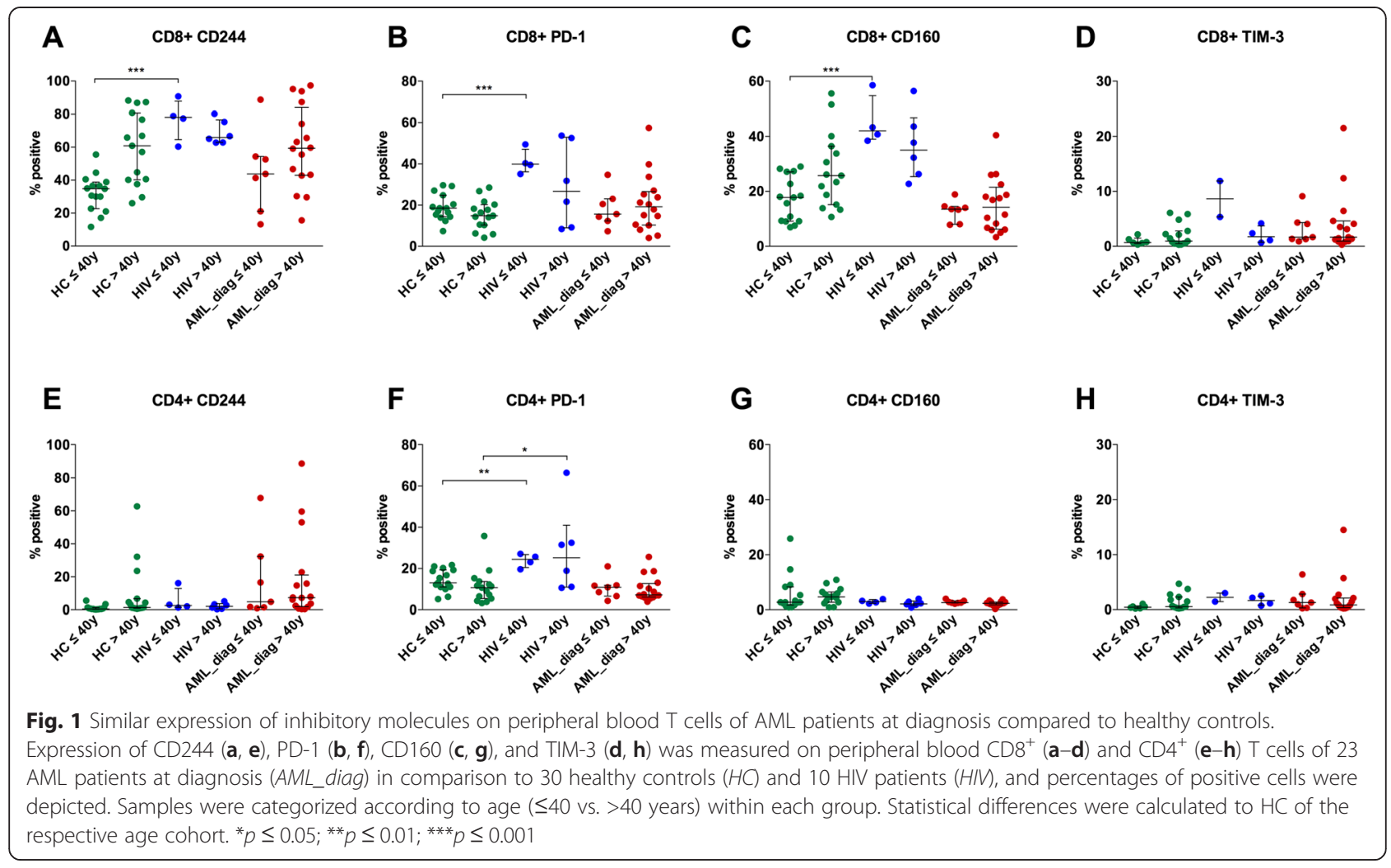

TIM-3 median of 1.7; Fig. 1a-d) nor for the older cohort (CD244 median of 59.4; PD-1 median of 19.2; CD160 median of 14.2; TIM-3 median of 1.7; Fig. 1a-d). Similarly, expression levels of AML_diag on $\mathrm{CD}^{+}$cells were not elevated for any of the four molecules compared to HC (Fig. 1e-h).

\section{Increased levels of PD-1 were expressed on peripheral blood $\mathrm{CD}^{+}$and $\mathrm{CD}^{+}{ }^{+}$cells of $\mathrm{AML}$ patients at relapse after allogeneic SCT compared to diagnosis}

As inhibitory molecule expression in AML_diag was unaltered, we went on to study the relapse situation. Immunophenotyping of $\mathrm{PB} \mathrm{CD}^{+} \mathrm{T}$ cells was performed for 8 patients with an AML relapse after intensive chemotherapy (AML_rel) and 6 patients with an AML relapse after allo-SCT (AML_rel_allo), each before the start of any cytotoxic treatment in the relapse situation, and results were compared to the 16 AML_diag specified above. Patient selection was limited to the age cohort $>40$ years (Fig. 2).

Both for $\mathrm{CD}^{+} \mathrm{T}$ cells and for $\mathrm{CD}^{+} \mathrm{T}$ cells, a strong upregulation of PD-1 was seen in AML_rel_allo compared to AML_diag $\left(\mathrm{CD}^{+}\right.$: median of 51.1 vs. $19.2 ; p=0.02$; Fig. $2 \mathrm{~b}$; $\mathrm{CD}^{+}$: median of 63.5 vs. $7.2 ; p<0.0001$; Fig. $2 \mathrm{f}$ ). The samples from AML_rel did not show a PD-1 upregulation (median of 13.3 and 12.7, respectively; Fig. 2b, f). For CD244, there was a trend towards higher expression in AML_rel $\left(\mathrm{CD}^{+}\right.$: median of 78.7 vs. $59.4 ; p=0.05$; Fig. $2 \mathrm{a}$;
$\mathrm{CD}^{+}$: median of 11.0 vs. $7.3 ; p=0.45$; Fig. $\left.2 \mathrm{e}\right)$, but no difference in AML_rel_allo $\left(\mathrm{CD}^{+}\right.$: median of 69.6; Fig. 2a; $\mathrm{CD}^{+}$: median of 2.4; Fig. 2e). For CD160 (Fig. 2c, g) and TIM-3 (Fig. 2d, h), no significant differences in expression levels between the patient groups were found.

Increased levels of PD-1 were expressed on bone marrow $\mathrm{CD}^{+}$and $\mathrm{CD}^{+}{ }^{+} \mathrm{T}$ cells of $\mathrm{AML}$ patients at relapse after allogeneic SCT compared to diagnosis

As the microenvironment in the BM might influence $\mathrm{T}$ cell activation and exhaustion, we analyzed $\mathrm{BM}$ $\mathrm{CD}^{+} \mathrm{T}$ cells for $5 \mathrm{HC}, 31$ AML_diag, 7 AML_rel, and 6 AML_rel_allo. Analysis was limited to the age cohort $>40$ years (Fig. 3 ).

In contrast to $\mathrm{PB} \mathrm{CD} 3^{+} \mathrm{T}$ cells, increased CD244 expression was clearly detectable in all AML BM samples, both on $\mathrm{CD}^{+}$and on $\mathrm{CD}^{+}{ }^{+} \mathrm{T}$ cells. Expression on $\mathrm{HC}$ $\mathrm{BM} \mathrm{T}$ cells was in the range of the $\mathrm{PB}$ samples $\left(\mathrm{CD}^{+}\right.$: median of 40.2; $\mathrm{CD}^{+}$: median of 3.7$)$, but expression in AML_diag $\left(\mathrm{CD}^{+}\right.$: median of $72.3 ; p=0.0008 ; \mathrm{CD}^{+}$: median of $24.7 ; p<0.0001)$, AML_rel $\left(\mathrm{CD}^{+}\right.$: median of $65.9 ; p=0.07 ; \mathrm{CD}^{+}$: median of $\left.16.6 ; p=0.003\right)$, and AML_rel_allo $\left(\mathrm{CD}^{+}\right.$: median of $89.9 ; p=0.004 ; \mathrm{CD}^{+}$: median of 22.6; $p=0.004$ ) was upregulated (Fig. 3a, e). Only for $\mathrm{CD}^{+} \mathrm{T}$ cells, CD244 expression on AML_rel_allo was significantly higher than on AML_diag $(p=0.01$; Fig. 3a). 

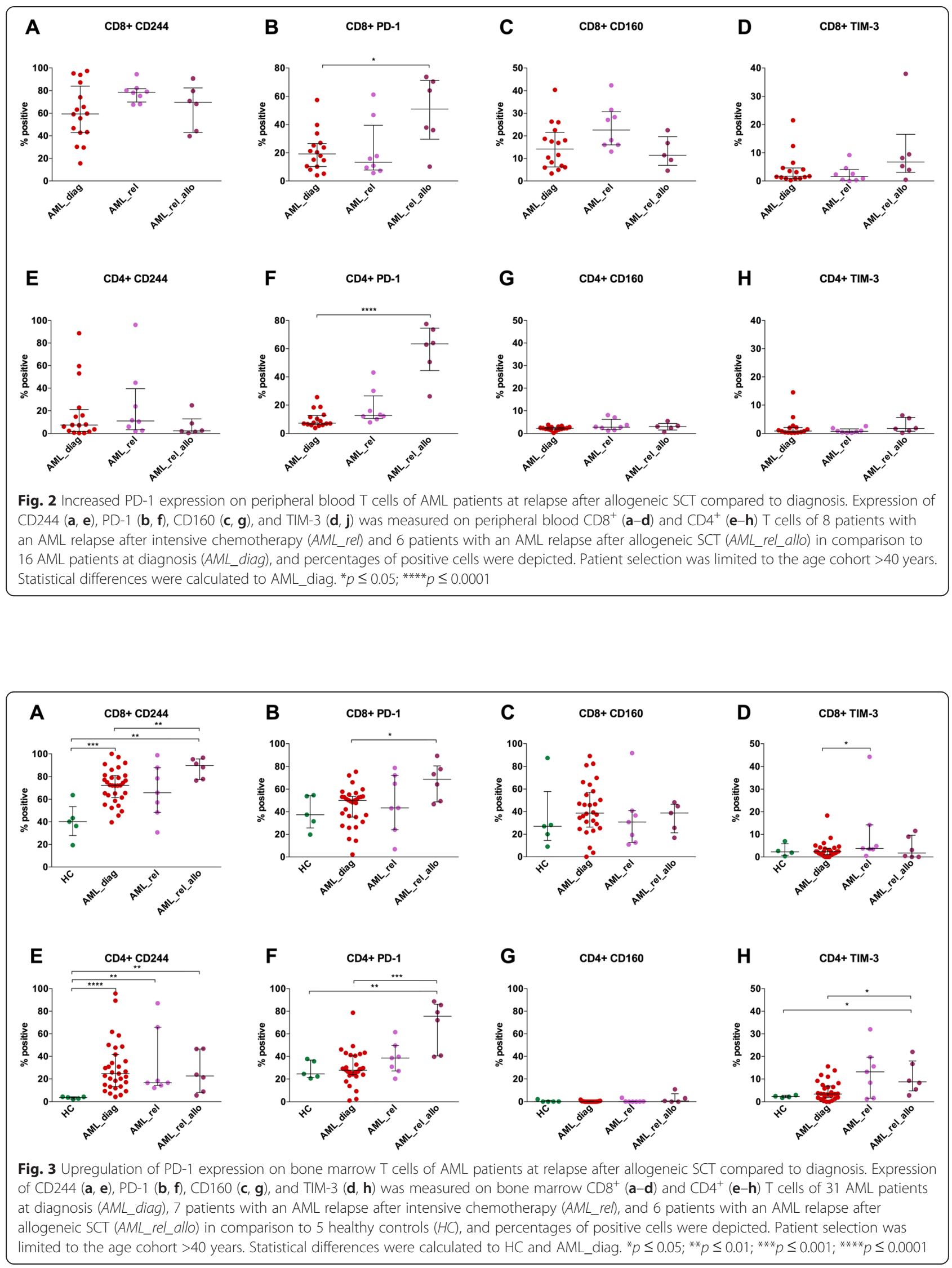
Upregulation of PD-1 was found for AML_rel_allo in comparison to AML_diag, for $\mathrm{CD}^{+} \mathrm{T}$ cells (median of 68.7 vs. $50.0 ; p=0.02$; Fig. $3 \mathrm{~b}$ ) as well as for $\mathrm{CD} 4^{+} \mathrm{T}$ cells (median of 75.6 vs. 27.8; $p=0.0005$; Fig. 3f). For $\mathrm{CD}_{4}{ }^{+} \mathrm{T}$ cells, the difference of $\mathrm{PD}-1$ expression in AML_rel_allo was also significant compared to $\mathrm{HC}$ (median of 24.5; $p=0.004$; Fig. 3f), while the level of significance was not reached for $\mathrm{CD}^{+} \mathrm{T}$ cells in spite of a strong trend (HC: median of $37.4 ; p=0.05$; Fig. 3b).

$\mathrm{CD}^{+}{ }^{+} \mathrm{T}$ cells from AML_rel_allo also showed increased expression of TIM-3 compared to HC (median of 8.8 vs. $2.3 ; p=0.02$ ) as well as compared to AML_diag (median of 3.3; $p=0.03$; Fig. 3h), with a similar trend for AML_rel (median of 13.2 vs. 2.3 for HC; $p=0.30$; median of 3.3 for AML_diag; $p=0.06$; Fig. $3 \mathrm{~h}$ ). For $\mathrm{CD}^{+} \mathrm{T}$ cells, there was a significantly higher expression of TIM-3 in AML_rel compared to AML_diag (median of 3.8 vs. $2.4 ; p=0.05$; Fig. 3 d). For CD160 (Fig. 3c, g), no significant differences in expression levels between $\mathrm{HC}$ and the various AML patient groups were found.

\section{CMV serostatus was not associated with expression pattern of inhibitory molecules}

In order to exclude that the expression of CD244 and PD-1 on T cells is merely related to CMV status, we analyzed the expression of the inhibitory molecules on $\mathrm{CD}^{+} \mathrm{T}$ cells and on $\mathrm{CD} 4^{+} \mathrm{T}$ cells in $24 \mathrm{HC}$ with confirmed seropositivity or seronegativity for CMV within two different age cohorts ( $\leq 40$ vs. $>40$ years). No difference in expression levels with respect to CMV serostatus was found for CD244, PD-1, CD160, and TIM-3 (Additional file 1: Figure S1).

\section{Relapsed AML patients showed shift towards differentiated effector $\mathrm{T}$ cell phenotype}

Next, we analyzed whether the distribution of $T$ memory subsets and activation status differed between the various patient cohorts, as a skewing of the $\mathrm{T}$ cell compartment towards antigen-experienced memory cells might contribute to the observed increase in PD-1 expression in AML_rel_allo. CD45RA and CCR7 expression was measured on $\mathrm{PB} \mathrm{CD}^{+}$and $\mathrm{CD}^{+}{ }^{+} \mathrm{T}$ cells of $19 \mathrm{AML}_{-}$ diag, 9 AML_rel, and 7 AML_rel_allo, in comparison to $21 \mathrm{HC}$ and $8 \mathrm{HIV}$ patients, and percentages of naïve (Tnaive; $\mathrm{CD}^{2} 5 \mathrm{RA}^{+} / \mathrm{CCR}^{+}$) and effector memory (Tem; $\mathrm{CD}^{2} 5 \mathrm{RA}^{-} / \mathrm{CCR}^{-}$) $\mathrm{CD}^{+}{ }^{+}$and $\mathrm{CD} 4^{+} \mathrm{T}$ cells were plotted as a variable of age (Fig. 4). For $\mathrm{CD}^{+} \mathrm{T}$ cells of $\mathrm{HC}$, we observed a strong decline of Tnaive with age, a pattern that has been described previously [39] and that we could also confirm for AML_diag (Fig. 4a). The percentage of Tem was independent of age (Fig. 4b). In contrast, HIV patients as well as relapsed AML patients (both AML_rel and AML_rel_allo) showed lower percentages of Tnaive and higher percentages of Tem across all age groups (Fig. 4a, b). For $\mathrm{CD}^{+} \mathrm{T}$ cells, we similarly observed decreased Tnaive frequencies (Fig. 4c) and an increased proportion of Tem (Fig. 4d) for HIV patients and relapsed AML patients.

Additionally, the proportion of $\mathrm{CD}^{-} 7^{-}$cells was determined for $\mathrm{CD}^{+}$and $\mathrm{CD}_{4}^{+}$T cells of 19 AML_diag, 9 AML_rel, and 7 AML_rel_allo in comparison to $27 \mathrm{HC}$ and 8 HIV patients to account for the more differentiated cells (Additional file 2: Figure S2). AML_diag showed a similar proportion of $\mathrm{CD}^{-} 7^{-}$cells as $\mathrm{HC}\left(\mathrm{CD}^{+}\right.$: median of 19.8 vs. $14.7 ; p=0.46 ; \mathrm{CD}^{+}$: median of 6.9 vs. 7.4 ; $p=0.92$ ), while increased proportions were observed for HIV patients $\left(\mathrm{CD}^{+}\right.$: median of $46.8 ; p=0.01 ; \mathrm{CD}^{+}$: median of $18.5 ; p=0.006)$, AML_rel $\left(\mathrm{CD}^{+}\right.$: median of 39.7; $p=0.03$; $\mathrm{CD}_{4}^{+}$: median of $12.7 ; p=0.04$ ), and particularly AML_rel_allo $\left(\mathrm{CD}^{+}\right.$: median of $62.0 ; p=0.03$; $\mathrm{CD}^{+}$: median of $30.6 ; p=0.002$ ).

\section{Differentiated effector $\mathrm{T}$ cells exhibited higher expression of CD244 and PD-1}

In order to evaluate whether the differences in inhibitory molecule expression described above are due to the observed shift towards differentiated effector cells, we analyzed the expression of CD244 and PD-1 in the different $\mathrm{CD}^{+} \mathrm{T}$ cell subsets of AML_diag $(n=14$ and $n=10)$, AML_rel $(n=9$ and $n=9)$, and AML_rel_allo ( $n=6$ and $n=4$; Fig. 5) in comparison to $\mathrm{HC}(n=9$ and $n=5$ ). In general, similar levels of CD244 as well as PD-1 expression were observed within the same $T$ memory subset of the different cohorts, with only minor increases of PD-1 expression in AML_rel (median of 24.9 vs. $18.5 ; p=0.02$ ) and AML_rel_allo (median of 44.3 vs. $18.5 ; p=0.02$ ) for Tnaive (Fig. 5 c). Most importantly, the subset with the highest expression of the inhibitory molecules, Tem, showed similar expression levels in all cohorts (Fig. 5b, d).

\section{T cells of AML patients were functionally intact}

Finally, proliferation and cytokine production capacity of PB CD3 ${ }^{+}$T cells were tested for AML_diag ( $n=7$ and $n=11)$, AML_rel $(n=5$ and $n=7)$, and AML_rel_allo ( $n=3$ and $n=4)$, with HC ( $n=8$ and $n=20)$ as control (Fig. 6). Additionally, 4 HIV patients served as a positive control in the cytokine production assay. No proliferation defect was found for any of the AML patient groups, neither for $\mathrm{CD}^{+}$(Fig. 6a) nor for $\mathrm{CD} 4^{+}$(Fig. 6b) $\mathrm{T}$ cells when stimulated with $\mathrm{CD} 3 / \mathrm{CD} 28$ beads. Cytokine secretion of HIV $\mathrm{T}$ cells was impaired for IFN- $\gamma$ $\left(\mathrm{CD}^{+}\right.$: median of 43.7 vs. $68.5 ; p=0.22$; Fig. 6 c; $\mathrm{CD}^{+}{ }^{+}$: median of 11.6 vs. $18.1 ; p=0.28$; Fig. $6 \mathrm{~d})$, TNF- $\alpha\left(\mathrm{CD}^{+}\right.$: median of 50.0 vs. $74.1 ; p=0.06$; Fig. $6 \mathrm{e} ; \mathrm{CD}^{+}$: median of 56.0 vs. 81.2 ; $p=0.01$; Fig. 6 f), and IL-2 $\left(\mathrm{CD}^{+}\right.$: median of 11.7 vs. $30.4 ; p<0.0001$; Fig. 6 ; $\mathrm{CD}^{+}$: median 


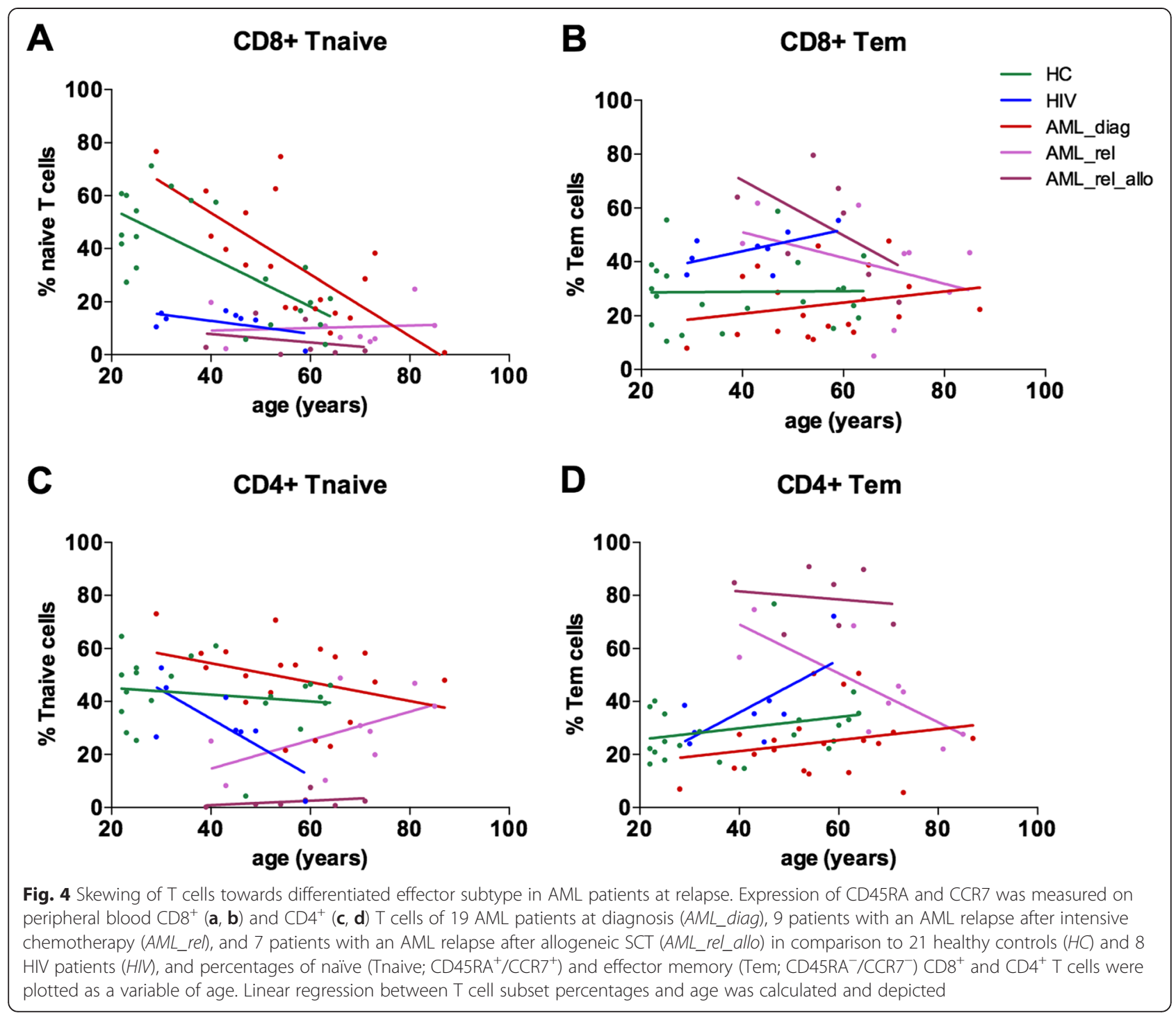

of 21.6 vs. $50.4 ; p=0.007$; Fig. 6 h), although statistical significance was not always reached due to the sample size. In contrast, cytokine secretion of all three AML patient cohorts was not impaired when stimulated with phorbol myristate acetate (PMA) and ionomycin, both for $\mathrm{CD}^{+}$and for $\mathrm{CD}^{+} \mathrm{T}$ cells, with the sole exception of decreased IFN- $\gamma$ production of $\mathrm{CD}^{+} \mathrm{T}$ cells in AML_diag (median of 7.7 vs. $18.1 ; p=0.0002$; Fig. $6 \mathrm{~d}$ ).

\section{Discussion}

Many novel immunotherapeutic strategies in AML including bispecific antibodies, CAR T cells, checkpoint inhibitors, and vaccinations rely on $\mathrm{T}$ cell function. For the optimal application and timing of these therapies, it is therefore of utmost importance to have detailed knowledge about the characteristics of $\mathrm{T}$ cells during the disease. Phenotypic changes and functional defects associated with $\mathrm{T}$ cell exhaustion have been described in patients with solid cancers $[40,41]$ and hematologic malignancies [12-15]. The most detailed studies of $\mathrm{T}$ cell status have been conducted in patients with CLL. An increased expression of CD244, PD-1, and CD160 was described on T cells of untreated CLL patients, preferentially on the $\mathrm{CD}^{+}$ effector cells, accompanied by defects in proliferation and cytotoxicity, but at the same time, increased production of IFN- $\gamma$ and TNF- $\alpha$ [17]. Within CLL patients in an early stage of disease, higher PD-1 positivity among $\mathrm{CD}^{+} \mathrm{T}$ cells was shown to be associated with worse prognosis [16]. Chemotherapy seemed to increase the expression of inhibitory receptors (CD244, PD-1) on $\mathrm{T}$ cells of CLL patients, while lenalidomide reversed this effect [18].

In comparison, little data is available on different aspects of T cell number, phenotype, and function in AML patients. An early study described an increase of some activation 


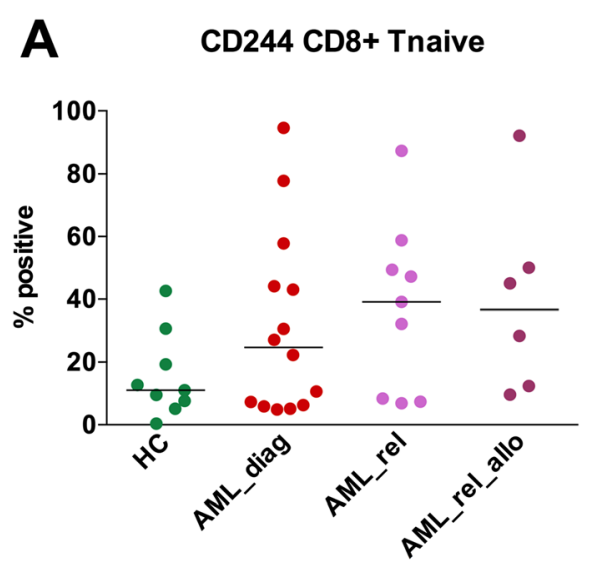

C



B $\quad$ CD244 CD8+ Tem

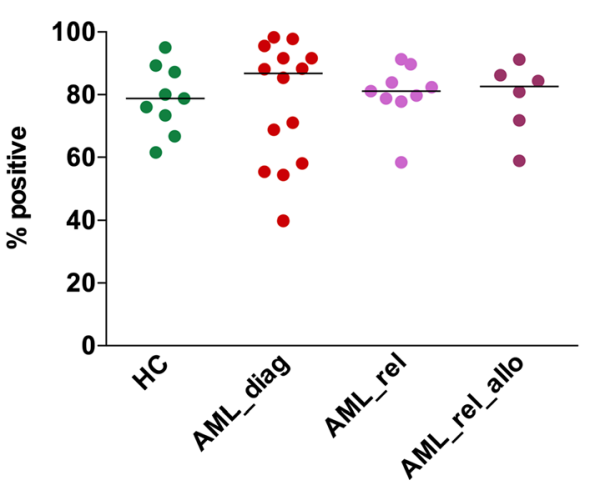

$\mathbf{D}$ PD-1 CD8+ Tem

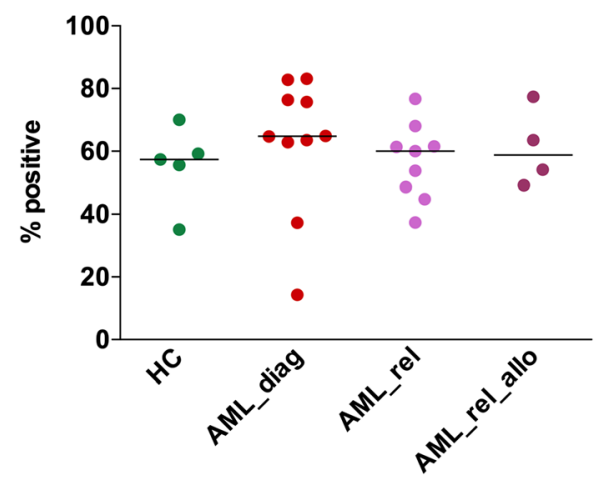

Fig. 5 Elevated CD244 and PD-1 expression on differentiated effector T cells. Peripheral blood CD8 ${ }^{+} T$ cells were classified into naïve (Tnaive; CD45RA ${ }^{+} / \mathrm{CCR7}^{+},(\mathbf{a}, \mathbf{c})$ ) and effector memory $\left(T e m ; \mathrm{CD}_{5} \mathrm{RA}^{-} / \mathrm{CCR}^{-},(\mathbf{b}, \mathbf{d})\right) \mathrm{T}$ cells, and expression of CD244 (a, b) and PD-1 (c, d) was measured for AML patients at diagnosis (AML_diag; $n=14$ and $n=10)$, patients with an AML relapse after intensive chemotherapy (AML_rel; $n=9$ and $n=9)$, and patients with an AML relapse after allogeneic SCT (AML_rel_allo; $n=6$ and $n=4)$ in comparison to healthy controls $(H C, n=9$ and $n=5$ ). Percentages of positive cells were depicted. Statistical differences were calculated to HC. ${ }^{*} p \leq 0.05$

markers (HLA-DR, CD69, CD71, CD57) on T cells at diagnosis [42]. This was in line with data from gene expression profiling of $\mathrm{T}$ cells providing some hints at aberrant $\mathrm{T}$ cell activation in AML patients [43]. Patients in complete remission after intensive chemotherapy had normal $\mathrm{CD}^{+} \mathrm{T}$ cell counts but reduced numbers of $\mathrm{CD}^{+} \mathrm{T}$ cells and Tregs, and the proliferation of $\mathrm{CD} 4^{+} \mathrm{T}$ cells was not impaired [44]. During chemotherapy-induced leukopenia, however, when $\mathrm{T}$ cell counts are very low, the remaining $\mathrm{T}$ cells were shown to be functionally impaired and to need optimal costimulation in order to proliferate [45]. Antigenspecific $\mathrm{CD}^{+} \mathrm{T}$ cell responses are generally very rare in AML and were only studied after allo-SCT. In this setting, increased PD-1 levels on MiHA-specific $\mathrm{CD}^{+}{ }^{+} \mathrm{T}$ cells [46] and the existence of a special subset of TNF- $\alpha^{+} / \mathrm{IFN}-\gamma^{-} \mathrm{T}$ cells without further characterization [47] were described.

However, expression levels of inhibitory molecules associated with $\mathrm{T}$ cell exhaustion and the functional status of $\mathrm{T}$ cells at different phases of the disease have not been studied. We report here that $\mathrm{CD} 8^{+}$and $\mathrm{CD} 4^{+} \mathrm{T}$ cells in $\mathrm{PB}$ as well as in BM of AML patients at relapse after allo-SCT showed increased expression of PD-1, in contrast to T cells of AML patients at diagnosis.

Inhibitory molecules on $\mathrm{CD} 4^{+} \mathrm{T}$ cells have not been studied as broadly as on $\mathrm{CD}^{+} \mathrm{T}$ cells. However, the same molecules also seem to play a role in $\mathrm{CD}^{+} \mathrm{T}$ cells. Similarly to $\mathrm{CD}^{+} \mathrm{T}$ cells, persistent antigen exposure can induce a dysfunctional state in $\mathrm{CD}_{4}^{+} \mathrm{T}$ cells [48], which correlates with PD- 1 expression $[49,50]$. Tregs are unlikely to account for the observed increased expression of PD-1 on CD4 $4^{+} \mathrm{T}$ cells, as freshly isolated Tregs from healthy volunteers have been reported to express PD-1 solely intracellularly [51].

We were able to demonstrate that the inhibitory molecule expression pattern was independent of age and CMV status. Instead, high expression of CD244 and PD-1 was associated with $\mathrm{T}$ cell memory subset distribution. As had been described before [39], we 

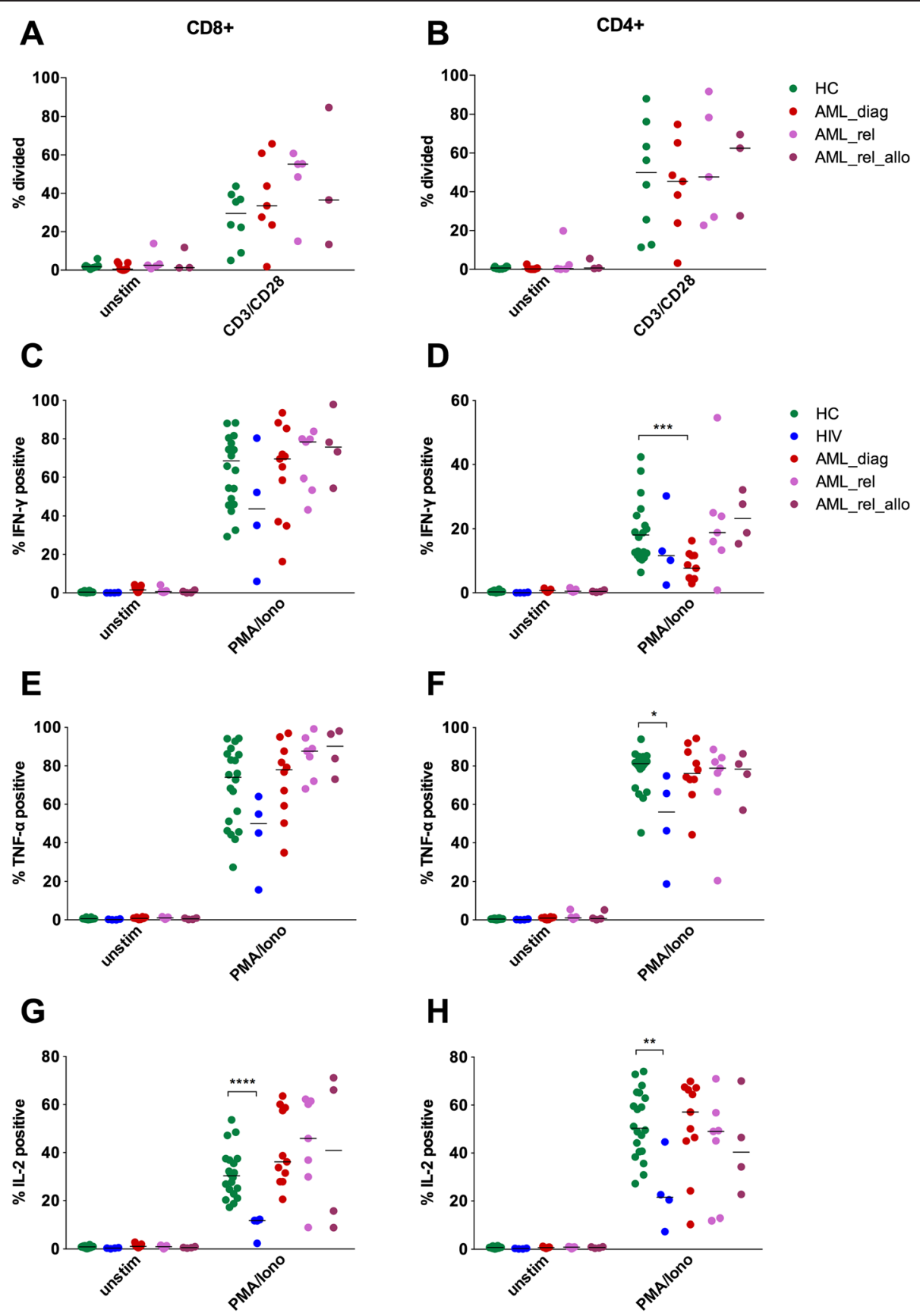

Fig. 6 Functional integrity of T cells from AML patients. Proliferation $(\mathbf{a}, \mathbf{b})$ and production of IFN- $\gamma(\mathbf{c}, \mathbf{d})$, TNF-a $(\mathbf{e}, \mathbf{f})$, and IL-2 (g, h) with or without an unspecific stimulus were analyzed for peripheral blood $\operatorname{CD}^{+}(\mathbf{a}, \mathbf{c}, \mathbf{e}, \mathbf{g})$ and $\mathrm{CD}^{+}(\mathbf{b}, \mathbf{d}, \mathbf{f}, \mathbf{h}) \mathrm{T}$ cells of AML patients at diagnosis (AML_diag; $n=7$ for proliferation and $n=11$ for cytokines), patients with an AML relapse after intensive chemotherapy (AML_rel; $n=5$ and $n=7$ ), and patients with an AML relapse after allogeneic SCT (AML_rel_allo; $n=3$ and $n=4$ ) in comparison to healthy controls ( $H C ; n=8$ and $n=20$ ). Four HIV patients (HIV) served as an additional control for diminished cytokine production. Percentages of divided (a, $\mathbf{b})$ or of positive $(\mathbf{c}-\mathbf{h})$ cells were depicted. Statistical differences were calculated to HC. ${ }^{*} p \leq 0.05 ;{ }^{* *} p \leq 0.01 ;{ }^{* * *} p \leq 0.001 ;{ }^{* * *} p \leq 0.0001$

found that the numbers of naïve $\mathrm{T}$ cells decline with age. However, we saw that patients with a relapse had a significantly higher proportion of effector memory $\mathrm{T}$ cells, independent of age. This shift was clearly detectable as an increase in the $\mathrm{CCR} 7^{-} / \mathrm{CD}_{4} 5 \mathrm{RA}^{-}$subset as well as in $\mathrm{CD}_{2} 7^{-} \mathrm{T}$ cells, which have been described to be more differentiated [39, 52]. We could show that the subset of effector memory $\mathrm{T}$ cells inherently expressed higher levels of CD244 and PD-1, in healthy controls as well as across all patient cohorts. Therefore, 
we concluded that the increase in inhibitory molecule expression was most likely a surrogate for a shift towards differentiated effector $\mathrm{T}$ cells instead of a sign for $\mathrm{T}$ cell exhaustion. This is in line with the emerging notion that $\mathrm{T}$ cells with the characteristics defining exhaustion might rather be chronically activated [53].

Supporting our results, it has recently been shown in a study of healthy controls that inhibitory receptor expression depends more dominantly on differentiation and activation than on exhaustion of $\mathrm{CD} 8^{+} \mathrm{T}$ cells [53]. The increased expression of PD-1 on T cells of CLL patients was also found to be accompanied by a shift towards effector memory cells [54]. Similarly, in a very detailed study on T cell status in CLL, it was described that inhibitory molecule expression correlated with a skewing of $\mathrm{T}$ cells towards effector differentiation, although this study did not analyze patients after allogeneic SCT [17]. Supposedly, chronic antigen stimulation accounts for this shift in subsets. Importantly, however, functional defects were described for the $\mathrm{T}$ cells in CLL, particularly concerning proliferation and cytotoxicity [17], although it was demonstrated, on the other side, that $\mathrm{CMV}$-specific $\mathrm{CD}^{+} \mathrm{T}$ cell function was not impaired [55].

In our study, we did not detect relevant functional impairment with respect to proliferation or cytokine production in $\mathrm{T}$ cells from AML patients at diagnosis or at relapse. Cytokine production was measured after antigen-unspecific $\mathrm{T}$ cell stimulation based on PMA and ionomycin, which bypasses TCR signaling. Unfortunately, antileukemic $\mathrm{T}$ cell responses were too rare to be measured. Even CD3/CD28 stimulation only resulted in very small $\mathrm{T}$ cell responses in such a setting. After stimulation with PMA and ionomycin, however, we observed compromised cytokine production in HIV patients. We therefore conclude that we can at least detect a functional defect downstream of TCR signaling this way. Our data are perfectly in line with a recent publication showing that the expression of PD- 1 and CD244 on $\mathrm{CD}^{+} \mathrm{T}$ cells marks differentiated cells that intrinsically produce more cytokines [53]. The sole deficit found was a significantly decreased IFN- $\gamma$ production of $\mathrm{CD}^{+} \mathrm{T}$ cells in diagnosis patients, but not in patients with an AML relapse. To our knowledge, this has not been described before and could constitute an important observation with respect to the evolving immunotherapeutic options, as the reversal of this defect by Th1-polarizing therapies could be part of the therapeutic effects. More unspecifically, serum levels of cytokines and chemokines have been measured before, and different groups found either identical [56] or reduced levels [57] of IFN- $\gamma$ for untreated AML patients compared to healthy controls. Of course, our data applies to bulk T cells; therefore, antigen-specific $\mathrm{T}$ cells occurring at low frequencies could potentially vary from this pattern.

\section{Conclusions}

From the data presented here, we conclude that AML patients in the relapse situation show a skewing of their $\mathrm{T}$ cell compartment from naive towards differentiated effector cells, which is accompanied by an upregulation in inhibitory molecule expression, but not by a defect in their functional capacity. T cells of AML patients at diagnosis, in contrast, are not significantly different from those of agematched healthy controls, suggesting that increased $\mathrm{T}$ cell differentiation could be induced by a long-standing contact with AML cells in the sense of chronic stimulation. Therefore, while NK cell defects of AML patients have frequently been reported [58], our data implies that immunotherapeutic strategies relying on the functionality of autologous $\mathrm{T}$ cells, such as the application of bispecific antibodies or therapeutic vaccination, have particularly good prospects in the setting of AML.

\section{Methods}

\section{Sample collection}

After written informed consent in accordance with the Declaration of Helsinki and approval by the Institutional Review Board of the Ludwig-Maximilians-Universität (Munich, Germany), PB or BM samples were collected from $\mathrm{HC}$ and AML patients at diagnosis or relapse before the start of treatment. Patients were treated according to the German AML-CG treatment recommendations. Samples of HIV patients before start of highly active antiretroviral therapy (HAART) were collected at the Division of Clinical Infectiology at the Klinikum der Universität München. The cytomegalovirus (CMV) serostatus was determined at the Virology Department of the Max-von-Pettenkofer-Institute of the LudwigMaximilians-Universität.

\section{Immunophenotyping of lymphocytes}

Mononuclear cells (MCs) were isolated from $\mathrm{PB}$ or BM by Ficoll density gradient centrifugation. Immunofluorescent staining of cell surface antigens was performed using the following fluorescence-conjugated monoclonal antibodies: CD244 (PE or APC, C1.7), PD-1 (APC or Brilliant Violet 421, EH12.7H7), CD3 (AlexaFluor 488, UCHT1), CD45RA (Brilliant Violet 421, HI100), CCR7 (PE, G043H7), CD27 (APC, O323; all BioLegend, San Diego, CA, USA), CD160 (APC, 688327), TIM-3 (PE, 344823; both R\&D Systems, Minneapolis, MN, USA), CD8 (PerCP-eFluor 710, SK1; eBioscience, San Diego, CA, USA), and CD4 (APC-H7, RPA-T4; BD Biosciences, San Jose, CA, USA). Corresponding isotype controls were used. $\mathrm{PB}$ and $\mathrm{BM}$ cells were analyzed using LSR II (BD Biosciences, Heidelberg, Germany) and Navios (Beckman Coulter, Krefeld, Germany) instruments, respectively. Post-acquisition analysis was performed using Flowjo software (version 9.6; Tree Star, Ashland, OR, USA). 


\section{CFSE proliferation assay}

$\mathrm{CD}^{+} \mathrm{T}$ cells were isolated from fresh or frozen PBMCs of $\mathrm{HC}$ and AML patients by MACS (Miltenyi Biotec, Bergisch Gladbach, Germany) labeled with $0.625 \mu \mathrm{m}$ CFSE (Life Technologies, Carlsbad, CA, USA), and cultured in the presence of Dynabeads Human T-Activator CD3/CD28 (Life Technologies GmbH, Darmstadt, Germany) at a bead-to-cell ratio of 1:3 for 7 days. Unstimulated cells served as negative control. Harvested cells were then stained with antibodies for CD3 (APC, UCHT1; BioLegend), CD4 (APC-H7, RPA-T4; BD Biosciences), and CD8 (PerCP-eFluor 710, SK1; eBioscience).

\section{Cytokine production assay}

Isolated $\mathrm{CD}^{+} \mathrm{T}$ cells were stimulated with PMA (20 $\mu \mathrm{g} / \mathrm{ml})$ and Ionomycin $(750 \mathrm{ng} / \mathrm{ml}$; both Sigma-Aldrich, St. Louis, MO, USA) after overnight resting. After $1 \mathrm{~h}$, Golgi stop solution consisting of Monensin at $25 \mu \mathrm{M}$ and Brefeldin A at $10 \mu \mathrm{g} / \mathrm{ml}$ (both Sigma-Aldrich) was added for additional $5 \mathrm{~h}$. Harvested cells were surface stained for CD3 (AlexaFluor 488, UCHT1; BioLegend), CD4 (APC-H7, RPA-T4; BD Biosciences), and CD8 (PerCP-eFluor 710, SK1; eBioscience) and intracellularly with the BD Cytofix/Cytoperm Kit (BD Biosciences) and antibodies for IFN- $\gamma$ (PE, B27), IL-2 (Brilliant Violet 421, MQ1-17H12), and TNF- $\alpha$ (APC, MAb11; all BioLegend).

\section{Statistical analysis}

Data was analyzed using Prism 6 (GraphPad Software, La Jolla, CA, USA) and is reported in scatter plots. Statistical significance of differences was determined using the Mann-Whitney $U$ test. $p \leq 0.05$ was considered statistically significant (* in all figures), $p \leq 0.01$ is designated with ${ }^{* *}, p \leq 0.001$ with ${ }^{* * * *}$, and $p \leq 0.0001$ with $* * * *$.

\section{Additional files}

Additional file 1: Figure S1. No association of inhibitory molecule expression with CMV serostatus. Expression of CD244 (A, E), PD-1 (B, F), CD160 $(C, G)$, and TIM-3 $(D, H)$ was measured on peripheral blood $C D 8^{+}(A-D)$ and $\mathrm{CD}^{+}(\mathrm{E}-\mathrm{H}) \mathrm{T}$ cells of 24 healthy controls $(\mathrm{HC})$, and percentages of positive cells were depicted. Samples were categorized according to age ( $\leq 40$ vs. $>40$ years) and $\mathrm{CMV}$ serostatus $\left(\mathrm{CMV}^{+}\right.$or $\left.\mathrm{CMV}^{-}\right)$. No statistical differences between $\mathrm{CMV}^{+}$and $\mathrm{CMV}^{-}$were found. (TIFF $1310 \mathrm{~kb}$ )

Additional file 2: Figure S2. Increased percentages of differentiated $\mathrm{CD}^{-} 7^{-} \mathrm{T}$ cells in AML patients at relapse. Expression of CD27 was measured on peripheral blood $\mathrm{CD}^{+}(\mathrm{A})$ and $\mathrm{CD}^{+}(\mathrm{B}) \mathrm{T}$ cells of $19 \mathrm{AML}$ patients at diagnosis (AML_diag), 9 patients with an AML relapse after intensive chemotherapy ( $A M L$ rel), and 7 patients with an $A M L$ relapse after allogeneic SCT (AML rel allo), in comparison to 27 healthy controls (HC) and 8 HIV patients (HIV), and percentages of CD27 cells were depicted. Statistical differences were calculated to $\mathrm{HC} .{ }^{*} p \leq 0.05$ ${ }^{* *} p \leq 0.01$. (TIFF $385 \mathrm{~kb}$ )

\section{Abbreviations}

allo-SCT: allogeneic stem cell transplantation; AML: acute myeloid leukemia; AML_diag: AML patients at diagnosis; $A M L$ rel: patients with an $A M L$ relapse after intensive chemotherapy; AML_rel_allo: patients with an AML relapse after allo-SCT; BM: bone marrow; CAR: chimeric antigen receptor; CLL: chronic lymphoid leukemia; CMV: cytomegalovirus; HAART: highly active antiretroviral therapy; HC: healthy control(s); HIV: human immunodeficiency virus; MC: mononuclear cell; PB: peripheral blood; PMA: phorbol myristate acetate.

\section{Competing interests}

The authors declare that they have no competing interests.

\section{Authors' contributions}

FMS, FSL, WH, and MS conceived and designed the experiments. FMS, KE MS, and JSN performed the experiments. RD provided the HIV samples. FMS, FSL, and MS analyzed the data and designed the figures. FSL and MS wrote the manuscript. All authors read and approved the final manuscript.

\section{Acknowledgements}

The work was supported by funds from the BaylmmuNet, the Bavarian Immunotherapy Network (http://www.bayimmunet.de), and by a Metiphys fellowship of the Medical Faculty of the Ludwig-Maximilian University Munich to FSL.

\section{Author details}

'Department of Internal Medicine III, Klinikum der Universität München, Munich, Germany. ${ }^{2}$ Clinical Cooperation Group Immunotherapy, Helmholtz Institute Munich, Munich, Germany. ${ }^{3}$ Division of Clinical Pharmacology, Department of Internal Medicine IV, Klinikum der Universität München, Munich, Germany. ${ }^{4}$ Division of Clinical Infectiology, Department of Internal Medicine IV, Klinikum der Universität München, Munich, Germany. ${ }^{5} \mathrm{Clinica}$ Cooperation Group Pathogenesis of Acute Myeloid Leukemia, Helmholtz Institute Munich, Munich, Germany.

Received: 25 February 2015 Accepted: 16 July 2015 Published online: 30 July 2015

\section{References}

1. Lichtenegger FS, Schnorfeil FM, Hiddemann W, Subklewe M. Current strategies in immunotherapy for acute myeloid leukemia. Immunotherapy. 2013:5(1):63-78.

2. Lichtenegger FS, Krupka C, Köhnke T, Subklewe M. Immunotherapy for acute myeloid leukemia. Semin Hematol. 2015;52(3):207-14.

3. Aigner M, Feulner J, Schaffer S, Kischel R, Kufer $P$, Schneider $K$, et al. T lymphocytes can be effectively recruited for ex vivo and in vivo lysis of $\mathrm{AML}$ blasts by a novel CD33/CD3-bispecific BiTE antibody construct. Leukemia. 2012;27(5):1107-15

4. Krupka C, Kufer P, Kischel R, Zugmaier G, Bögeholz J, Köhnke T, et al. CD33 target validation and sustained depletion of AML blasts in long-term cultures by the bispecific T-cell-engaging antibody AMG 330. Blood. 2014;123(3):356-65.

5. Laszlo GS, Gudgeon CJ, Harrington KH, Dell'Aringa J, Newhall KJ, Means GD, et al. Cellular determinants for preclinical activity of a novel CD33/CD3 bispecific T-cell engager (BiTE) antibody, AMG 330, against human AML. Blood. 2014:123(4):554-61.

6. Arndt C, von Bonin M, Cartellieri M, Feldmann A, Koristka S, Michalk I, et al. Redirection of T cells with a first fully humanized bispecific CD33-CD3 antibody efficiently eliminates AML blasts without harming hematopoietic stem cells. Leukemia. 2013:27(4):964-7.

7. Mardiros A, Dos Santos C, McDonald T, Brown CE, Wang X, Budde LE, et al. $T$ cells expressing CD123-specific chimeric antigen receptors exhibit specific cytolytic effector functions and anti-tumor effects against human acute myeloid leukemia. Blood. 2013;122(18):3138-48.

8. Ritchie DS, Neeson PJ, Khot A, Peinert S, Tai T, Tainton K, et al. Persistence and efficacy of second generation CAR T cell against the LeY antigen in acute myeloid leukemia. Mol Ther. 2013;21(11):2122-9.

9. Berger R, Rotem-Yehudar R, Slama G, Landes S, Kneller A, Leiba M, et al. Phase I safety and pharmacokinetic study of CT-011, a humanized antibody interacting with PD-1, in patients with advanced hematologic malignancies. Clin Cancer Res. 2008:14(10):3044-51.

10. Shi L, Chen S, Yang L, Li Y. The role of PD-1 and PD-L1 in T-cell immune suppression in patients with hematological malignancies. J Hematol Oncol. 2013;6(1):74. 
11. Andersen $\mathrm{MH}$. The targeting of immunosuppressive mechanisms in hematological malignancies. Leukemia. 2014;28(9):1784-92.

12. Shimauchi T, Kabashima K, Nakashima D, Sugita K, Yamada Y, Hino R, et al. Augmented expression of programmed death-1 in both neoplastic and non-neoplastic CD4+ T-cells in adult T-cell leukemia/lymphoma. Int J Cancer. 2007:121(12):2585-90.

13. Kozako T, Yoshimitsu M, Fujiwara H, Masamoto I, Horai S, White Y, et al. PD-1/PD-L1 expression in human T-cell leukemia virus type 1 carriers and adult T-cell leukemia/lymphoma patients. Leukemia. 2009:23(2):375-82.

14. Mumprecht S, Schürch C, Schwaller J, Solenthaler M, Ochsenbein AF Programmed death 1 signaling on chronic myeloid leukemia-specific T cells results in T-cell exhaustion and disease progression. Blood. 2009;114(8):1528-36.

15. Christiansson L, Söderlund S, Svensson E, Mustjoki S, Bengtsson M Simonsson B, et al. Increased level of myeloid-derived suppressor cells, programmed death receptor ligand 1/programmed death receptor 1, and soluble CD25 in Sokal high risk chronic myeloid leukemia. PLoS One. 2013;8(1), e55818.

16. Nunes C, Wong R, Mason M, Fegan C, Man S, Pepper C. Expansion of a CD8(+)PD-1(+) replicative senescence phenotype in early stage CLL patients is associated with inverted CD4:CD8 ratios and disease progression. Clin Cancer Res. 2012;18(3):678-87.

17. Riches JC, Davies JK, McClanahan F, Fatah R, lqbal S, Agrawal S, et al. T cells from CLL patients exhibit features of T-cell exhaustion but retain capacity for cytokine production. Blood. 2013;121(9):1612-21.

18. Gassner FJ, Zaborsky N, Neureiter D, Huemer M, Melchardt T, Egle A, et al. Chemotherapy-induced augmentation of $T$ cells expressing inhibitory receptors is reversed by treatment with lenalidomide in chronic lymphocytic leukemia. Haematologica. 2014:99(5):67-9.

19. Wherry EJ. T cell exhaustion. Nat Immunol. 2011;131(6):492-9.

20. Moskophidis D, Lechner F, Pircher H, Zinkernagel RM. Virus persistence in acutely infected immunocompetent mice by exhaustion of antiviral cytotoxic effector T cells. Nature. 1993;362(6422):758-61.

21. Gallimore A, Glithero A, Godkin A, Tissot AC, Plückthun A, Elliott T, et al. Induction and exhaustion of lymphocytic choriomeningitis virus-specific cytotoxic T lymphocytes visualized using soluble tetrameric major histocompatibility complex class I-peptide complexes. J Exp Med. 1998;187(9):1383-93.

22. Zajac AJ, Blattman JN, Murali-Krishna K, Sourdive DJ, Suresh M, Altman JD, et al. Viral immune evasion due to persistence of activated $T$ cells without effector function. J Exp Med. 1998;188(12):2205-13.

23. Day CL, Kaufmann DE, Kiepiela P, Brown JA, Moodley ES, Reddy S, et al. PD-1 expression on HIV-specific T cells is associated with T-cell exhaustion and disease progression. Nature. 2006:443(7109):350-4.

24. Yamamoto T, Price DA, Casazza JP, Ferrari G, Nason M, Chattopadhyay PK, et al. Surface expression patterns of negative regulatory molecules identify determinants of virus-specific CD8+ T-cell exhaustion in HIV infection. Blood. 2011:117(18):4805-15.

25. Peretz Y, He Z, Shi Y, Yassine-Diab B, Goulet JP, Bordi R, et al. CD160 and PD-1 co-expression on HIV-specific CD8 T cells defines a subset with advanced dysfunction. PLoS Pathog. 2012;8(8), e1002840.

26. Oxenius A, Zinkernagel RM, Hengartner $\mathrm{H}$. Comparison of activation versus induction of unresponsiveness of virus-specific CD4+ and CD8+ T cells upon acute versus persistent viral infection. Immunity. 1998;9(4):449-57.

27. Brooks DG, Teyton L, Oldstone MB, McGavern DB. Intrinsic functional dysregulation of CD4 T cells occurs rapidly following persistent viral infection. J Virol. 2005;79(16):10514-27

28. Chlewicki LK, Velikovsky CA, Balakrishnan V, Mariuzza RA, Kumar V. Molecular basis of the dual functions of 2B4 (CD244). J Immunol. 2008;180(12):8159-67.

29. Barber DL, Wherry EJ, Masopust D, Zhu B, Allison JP, Sharpe AH, et al. Restoring function in exhausted CD8 T cells during chronic viral infection. Nature. 2006;439(7077):682-7.

30. Nishimura $\mathrm{H}$, Nose M, Hiai $\mathrm{H}$, Minato $\mathrm{N}$, Honjo $\mathrm{T}$. Development of lupus-like autoimmune diseases by disruption of the PD-1 gene encoding an ITIM motif-carrying immunoreceptor. Immunity. 1999:11(2):141-51.

31. Dong H, Strome SE, Salomao DR, Tamura H, Hirano F, Flies DB, et al. Tumor-associated B7-H1 promotes T-cell apoptosis: a potential mechanism of immune evasion. Nat Med. 2002;8(8):793-800.
32. Cai G, Anumanthan A, Brown JA, Greenfield EA, Zhu B, Freeman GJ. CD160 inhibits activation of human CD4+ T cells through interaction with herpesvirus entry mediator. Nat Immunol. 2008;9(2):176-85.

33. Blackburn SD, Shin H, Haining WN, Zou T, Workman CJ, Polley A, et al. Coregulation of CD8+ T cell exhaustion by multiple inhibitory receptors during chronic viral infection. Nat Immunol. 2009;10(1):29-37.

34. Zhu C, Anderson AC, Schubart A, Xiong H, Imitola J, Khoury SJ, et al. The Tim-3 ligand galectin-9 negatively regulates $T$ helper type 1 immunity. Nat Immunol. 2005;6(12):1245-52

35. Jones RB, Ndhlovu LC, Barbour JD, Sheth PM, Jha AR, Long BR, et al. Tim-3 expression defines a novel population of dysfunctional T cells with highly elevated frequencies in progressive HIV-1 infection. J Exp Med. 2008;205(12):2763-79.

36. Fourcade J, Sun Z, Benallaoua M, Guillaume P, Luescher IF, Sander C, et al. Upregulation of Tim-3 and PD-1 expression is associated with tumor antigen-specific CD8+ T cell dysfunction in melanoma patients. J Exp Med. 2010;207(10):2175-86.

37. Sakuishi K, Apetoh L, Sullivan JM, Blazar BR, Kuchroo VK, Anderson AC. Targeting Tim-3 and PD-1 pathways to reverse $T$ cell exhaustion and restore anti-tumor immunity. J Exp Med. 2010;207(10):2187-94.

38. Zhou Q, Munger ME, Veenstra RG, Weigel BJ, Hirashima M, Munn DH, et al, Coexpression of Tim-3 and PD-1 identifies a CD8+ T-cell exhaustion phenotype in mice with disseminated acute myelogenous leukemia. Blood. 2011;117(17):4501-10.

39. Koch S, Larbi A, Derhovanessian E, Ozcelik D, Naumova E, Pawelec G. Multiparameter flow cytometric analysis of CD4 and CD8 T cell subsets in young and old people. Immun Ageing. 2008;5:6.

40. Ahmadzadeh M, Johnson LA, Heemskerk B, Wunderlich JR, Dudley ME, White DE, et al. Tumor antigen-specific CD8 T cells infiltrating the tumor express high levels of PD-1 and are functionally impaired. Blood. 2009;114(8):1537-44

41. Baitsch L, Baumgaertner P, Devêvre E, Raghav SK, Legat A, Barba L, et al. Exhaustion of tumor-specific CD8 ${ }^{+} \mathrm{T}$ cells in metastases from melanoma patients. J Clin Invest. 2011;121(6):2350-60.

42. Van den Hove LE, Vandenberghe P, Van Gool SW, Ceuppens IL, Demuynck H, Verhoef GE, et al. Peripheral blood lymphocyte subset shifts in patients with untreated hematological tumors: evidence for systemic activation of the T cell compartment. Leuk Res. 1998;22(2):175-84

43. Le Dieu R, Taussig DC, Ramsay AG, Mitter R, Miraki-Moud F, Fatah R, et al. Peripheral blood T cells in acute myeloid leukemia (AML) patients at diagnosis have abnormal phenotype and genotype and form defective immune synapses with AML blasts. Blood. 2009;114(18):3909-16.

44. Lichtenegger FS, Lorenz R, Gellhaus K, Hiddemann W, Beck B, Subklewe M. Impaired NK cells and increased T regulatory cell numbers during cytotoxic maintenance therapy in AML. Leuk Res. 2014;38(8):964-9.

45. Wendelbo $\varnothing$, Nesthus I, Sjo M, Paulsen K, Ernst $P$, Bruserud $\varnothing$. Functional characterization of $\mathrm{T}$ lymphocytes derived from patients with acute myelogenous leukemia and chemotherapy-induced leukopenia. Cancer Immunol Immunother. 2004;53(8):740-7.

46. Norde WJ, Maas F, Hobo W, Korman A, Quigley M, Kester MG, et al. PD-1/PD-L1 interactions contribute to functional T-cell impairment in patients who relapse with cancer after allogeneic stem cell transplantation. Cancer Res. 2011;71(15):5111-22.

47. Flörcken A, van Lessen A, Terwey TH, Dörken B, Arnold R, Pezzutto A, et al. Anti-leukemia T cells in AML: TNF- ${ }^{+} \mathrm{CD}^{+} \mathrm{T}$ cells may escape detection and possibly reflect a stage of functional impairment. Hum Vaccin Immunother. 2013:9(6):1200-4.

48. Han S, Asoyan A, Rabenstein H, Nakano N, Obst R. Role of antigen persistence and dose for CD4+ T-cell exhaustion and recovery. Proc Natl Acad Sci U S A. 2010;107(47):20453-8.

49. Antoine $P$, Olislagers $V$, Huygens $A$, Lecomte $S$, Liesnard C, Donner $C$, et al. Functional exhaustion of CD4+ T lymphocytes during primary cytomegalovirus infection. J Immunol. 2012;189(5):2665-72.

50. Dow C, Henderson R, Sette A, Mothé BR. CD4(+) T-cell inhibitory ligands: a tool for characterizing dysfunctional CD4(+) T cells during chronic infection. Immunology. 2013;140(1):61-9.

51. Raimondi G, Shufesky WJ, Tokita D, Morelli AE, Thomson AW. Regulated compartmentalization of programmed cell death-1 discriminates CD4+CD25+ resting regulatory $T$ cells from activated T cells. J Immunol. 2006:176(5):2808-16. 
52. Romero P, Zippelius A, Kurth I, Pittet MJ, Touvrey C, lancu EM, et al. Four functionally distinct populations of human effector-memory CD8+ T lymphocytes. J Immunol. 2007;178(7):4112-9.

53. Legat A, Speiser DE, Pircher H, Zehn D, Fuertes Marraco SA. Inhibitory receptor expression depends more dominantly on differentiation and activation than "exhaustion" of human CD8 T cells. Front Immunol. 2013:4:455.

54. Brusa D, Serra S, Coscia M, Rossi D, D'Arena G, Laurenti L, et al. The PD-1/PD-L1 axis contributes to T-cell dysfunction in chronic lymphocytic leukemia. Haematologica. 2013;98(6):953-63.

55. Te Raa GD, Pascutti MF, García-Vallejo JJ, Reinen E, Remmerswaal EB, Ten Berge IJ, et al. CMV-specific CD8+ T cell function is not impaired in chronic lymphocytic leukemia. Blood. 2013;123(5):717-24.

56. Fredly $H$, Reikvam H, Gjertsen BT, Bruserud O. Disease-stabilizing treatment with all-trans retinoic acid and valproic acid in acute myeloid leukemia: serum hsp70 and hsp90 levels and serum cytokine profiles are determined by the disease, patient age, and anti-leukemic treatment. Am J Hematol. 2012;87(4):368-76.

57. Kornblau SM, McCue D, Singh N, Chen W, Estrov Z, Coombes KR. Recurrent expression signatures of cytokines and chemokines are present and are independently prognostic in acute myelogenous leukemia and myelodysplasia. Blood. 2010;116(20):4251-61.

58. Lion E, Willemen Y, Berneman ZN, Van Tendeloo VF, Smits EL. Natural killer cell immune escape in acute myeloid leukemia. Leukemia. 2012;26(9):2019-26.

\section{Submit your next manuscript to BioMed Central and take full advantage of:}

- Convenient online submission

- Thorough peer review

- No space constraints or color figure charges

- Immediate publication on acceptance

- Inclusion in PubMed, CAS, Scopus and Google Scholar

- Research which is freely available for redistribution 